\title{
Airborne determination of the temporo-spatial distribution of benzene, toluene, nitrogen oxides and ozone in the boundary layer across Greater London, UK
}

\author{
M. D. Shaw ${ }^{1}$, J. D. Lee ${ }^{2}$, B. Davison ${ }^{1}$, A. Vaughan ${ }^{3}$, R. M. Purvis ${ }^{2}$, A. Harvey ${ }^{3}$, A. C. Lewis ${ }^{2}$, and C. N. Hewitt ${ }^{1}$ \\ ${ }^{1}$ Lancaster Environment Centre, Lancaster University, Lancaster, UK \\ ${ }^{2}$ National Centre for Atmospheric Science, University of York, York, UK \\ ${ }^{3}$ Department of Chemistry, University of York, York, UK
}

Correspondence to: C. N. Hewitt (n.hewitt@lancaster.ac.uk)

Received: 24 September 2014 - Published in Atmos. Chem. Phys. Discuss.: 30 October 2014

Revised: 18 February 2015 - Accepted: 31 March 2015 - Published: 5 May 2015

\begin{abstract}
Highly spatially resolved mixing ratios of benzene and toluene, nitrogen oxides $\left(\mathrm{NO}_{x}\right)$ and ozone $\left(\mathrm{O}_{3}\right)$ were measured in the atmospheric boundary layer above Greater London during the period 24 June to 9 July 2013 using a Dornier 228 aircraft. Toluene and benzene were determined in situ using a proton transfer reaction mass spectrometer (PTR-MS), $\mathrm{NO}_{x}$ by dual-channel $\mathrm{NO}_{x}$ chemiluminescence and $\mathrm{O}_{3}$ mixing ratios by $\mathrm{UV}$ absorption.

Average mixing ratios observed over inner London at $360 \pm 10 \mathrm{~m}$ a.g.l. were $0.20 \pm 0.05,0.28 \pm 0.07,13.2 \pm 8.6$, $21.0 \pm 7.3$ and $34.3 \pm 15.2 \mathrm{ppbv}$ for benzene, toluene, NO, $\mathrm{NO}_{2}$ and $\mathrm{NO}_{x}$ respectively. Linear regression analysis between $\mathrm{NO}_{2}$, benzene and toluene mixing ratios yields a strong covariance, indicating that these compounds predominantly share the same or co-located sources within the city.

Average mixing ratios measured at $360 \pm 10 \mathrm{~m}$ a.g.l. over outer London were always lower than over inner London. Where traffic densities were highest, the toluene/benzene (T/B) concentration ratios were highest (average of 1.8 $\pm 0.5 \mathrm{ppbv} \mathrm{ppbv}^{-1}$ ), indicative of strong local sources. Daytime maxima in $\mathrm{NO}_{x}$, benzene and toluene mixing ratios were observed in the morning $\left(\sim 40 \mathrm{ppbv} \mathrm{NO}_{x}, \sim 350 \mathrm{pptv}\right.$ toluene and $\sim 200$ pptv benzene) and in the mid-afternoon for ozone $\left(\sim 40 \mathrm{ppbv} \mathrm{O}_{3}\right)$, all at $360 \pm 10 \mathrm{~m}$ a.g.l.
\end{abstract}

\section{Introduction}

Ground-level ozone $\left(\mathrm{O}_{3}\right)$ is a secondary pollutant, produced from photochemical reactions involving volatile organic compounds (VOCs) and nitrogen oxides $\left(\mathrm{NO}_{x}=\mathrm{NO}\right.$ $+\mathrm{NO}_{2}$ ). Ozone has significant detrimental effects on human health and vegetation, while $\mathrm{NO}_{2}$ and some VOCs also have, themselves, direct effects on health. Whilst the basic atmospheric chemistry leading to $\mathrm{O}_{3}$ formation is generally well understood, there are substantial uncertainties associated with the magnitude and speciation of emissions of both VOCs and $\mathrm{NO}_{x}$ from urban areas, leading to uncertainties in the detailed understanding of urban photochemistry and air pollution.

In urban areas the dominant anthropogenic sources of VOCs are vehicular exhaust, fuel evaporation and emissions from the commercial and industrial use of solvents (Karl et al., 2009; Langford et al., 2010). Vehicular emissions are the predominant source of VOCs to the atmosphere in urban and suburban areas, accounting for $>50 \%$ of the total (Watson et al., 2001; Na et al., 2005; Kansal, 2009), with a wide range of VOCs emitted directly due to fuel evaporation and from vehicular exhaust as unburnt fuel and as partially oxidised fuel components. The dominant urban sources of $\mathrm{NO}_{x}$ are combustion processes, including vehicles. In the UK as a whole, about $50 \%$ of $\mathrm{NO}_{x}$ is thought to be derived from vehicles, although this percentage is larger in urban areas (Lee et al., 2015).

VOC and $\mathrm{NO}_{x}$ emissions from airports are also of importance, originating from a combination of emissions from 
aircraft exhaust, ground support equipment (GSE) exhaust and evaporative losses during aircraft refuelling (Carslaw et al., 2006). High mixing ratios of aromatic compounds, such as toluene and benzene, and low $\mathrm{NO}_{x}$ mixing ratios have been previously observed in jet engine exhaust immediately after ignition, attributed to low engine temperature causing incomplete combustion (Schürmann et al., 2007). Previous aircraft exhaust studies have shown that toluene/benzene (T/B) ratios observed during engine ignition are up to $3.1 \mathrm{ppbv} \mathrm{ppbv}^{-1}$, typical of kerosene fuel. At higher engine temperatures, i.e. during taxiing, higher aromatics tend to crack, leading to a reduced amount of these species but increasing amounts of benzene. Thus, for aircraft taxiing, a $\mathrm{T} / \mathrm{B}$ ratio of $\sim 0.5 \mathrm{ppbv} \mathrm{ppbv}^{-1}$ was previously observed (Spicer et al., 1994). Similarly, higher $\mathrm{NO}_{x}$ mixing ratios are observed due to higher engine combustion. As well as the contribution from aircraft, additional emissions from airport environments occur during the handling of aircraft with GSE. The GSE vehicles are mostly diesel-powered, leading to relatively high emission rates of the oxides of nitrogen. During aircraft refuelling, gaseous air-fuel mixtures are released from the aircraft tanks through fuel vents, which can be identified by the observed $\mathrm{T} / \mathrm{B}$ ratio, since kerosene fuel tends to have an enhanced amount of aromatic compounds. VOC emissions during engine refuelling were previously found to account for $2.7 \%$ of the total VOC emissions of Zurich airport (Schürmann et al., 2007).

Background and peak UK VOCs, $\mathrm{O}_{3}$ and $\mathrm{NO}_{2}$ mixing ratios are determined hourly by the national monitoring networks, such as the Automatic Hydrocarbon Network (AHN) and the Automatic Urban and Rural Network (AURN), both operated by the Department of Environment, Food and Rural Affairs. Hourly mixing ratios of $\mathrm{NO}_{x}$ species are currently measured at 130 network sites, with selected VOCs measured at 4 sites. Within Greater London, these sites form part of the London Air Quality Network (LAQN). However, measurements from these networks suffer from the limitations of being made at relatively few sites, and so may not be representative of mixing ratios on larger spatial scales.

The development of fast-response analytical instruments for $\mathrm{NO}_{x}$ and VOCs means that the mixing ratios of these analytes can now be measured at high spatial resolution from low-flying aircraft. The advantages of in situ aircraft measurements are that they provide information on the horizontal and vertical distributions of air pollutants over a large spatial area, allowing continuous gradients of mixing ratios to be observed across cities and their surrounding rural areas.

In this study, we investigate the mixing ratios of $\mathrm{O}_{3}$, benzene, toluene, $\mathrm{NO}, \mathrm{NO}_{2}$ and $\mathrm{NO}_{x}$ across the Greater London region during several flights using the Natural Environment Research Council (NERC) Atmospheric Research and Survey Facility Dornier 228 aircraft between 24 June and 9 July 2013. The aim of this work was to (i) quantitatively determine the vertical, horizontal, spatial and temporal distribution of VOCs, $\mathrm{NO}_{x}$ and ozone mixing ratios across
London from an airborne platform, with a view to identifying dominant emission sources in the region using measured $\mathrm{T} / \mathrm{B}$ concentration ratios and (ii) wherever possible, compare these fast-response airborne measurements with hourly ground-level measurements made by the national monitoring networks.

\section{Method}

\subsection{NERC Dornier 228}

The NERC Dornier 228 is a twin-engine turbo-proppowered, non-pressurised aircraft operated by the Airborne Research and Survey Facility (ARSF) based at Gloucester airport in central England. The aircraft has a cabin volume of $14 \mathrm{~m}^{3}$ and is operated with a crew of 2 pilots and 4 scientists for the duration of the flights. The aircraft has a minimum and maximum airspeed of 65 and $95 \mathrm{~m} \mathrm{~s}^{-1}$ respectively producing a maximum range of $2400 \mathrm{~km}$. The aircraft has a maximum payload of $5970 \mathrm{~kg}$ including fuel, with a maximum operational altitude for science of $4500 \mathrm{~m}$.

\subsection{Flight description}

Six research flights $(\mathrm{RF})$ totalling $15 \mathrm{~h}$ in duration were conducted between the hours of 8:30 and 17:20 UTC (Table 1). Figure 1a shows all flight legs conducted during the project, overlaid on a transport map of SE England. Here, we will focus on data obtained in transects across London. Figure $1 \mathrm{~b}$ shows a map of Greater London on which typical repeated south-westerly to north-easterly flight legs of $\sim 50 \mathrm{~km}$ are plotted. Identical flight legs across Greater London were chosen due to tight air traffic regulations and to allow data analysis in both a temporal and spatial domain. The grey area represents the Greater London boundary, the black area the inner London boundary and the blue area London's congestion charging zone (CCZ), in which road traffic is heavily regulated and subject to financial charging. Airspeed and altitude were fixed during the flights across Greater London with mean values of $73 \pm 3 \mathrm{~m} \mathrm{~s}^{-1}$ and $360 \pm 10 \mathrm{~m}$ a.g.l respectively (Table 1).

A north-westerly wind direction was observed during the flights, perpendicular to the flight transects (Table 1). Perpendicular wind directions are useful in providing a cross section of pollutant mixing ratios across London. RF 1 focussed on vertically profiling the PBL (planetary boundary layer) above London. Boundary layer (BL) height determinations were made from a combination of airborne observations and ground-based measurements. Approximately hourly lower cloud base altitude determinations were made from Heathrow airport using laser cloud-based recorder (LCBR) observations. The lowest observed cloud base was interpreted as the BL height. Where cloud-based observations were not available (during clear skies), temporally interpolated $\mathrm{BL}$ height determinations from aircraft observa- 
Table 1. Summary of meteorological and flight conditions during campaign.

\begin{tabular}{lllcccc}
\hline RF & Date & $\begin{array}{l}\text { Time } \\
(\text { local })\end{array}$ & $\begin{array}{c}\text { Mean wind } \\
\text { direction } \\
\left({ }^{\circ}\right.\end{array}$ & $\begin{array}{c}\text { Mean wind } \\
\text { speed } \\
\left(\mathrm{m} \mathrm{s}^{-1}\right)\end{array}$ & $\begin{array}{c}\text { Mean true } \\
\text { airspeed } \\
\left(\mathrm{m} \mathrm{s}^{-1}\right)\end{array}$ & $\begin{array}{c}\text { Mean flight } \\
\text { altitude } \\
\text { a.g.1 }(\mathrm{m})\end{array}$ \\
\hline 1 & $24 / 6 / 13$ & $15: 30-18: 20$ & $285.9 \pm 17.1$ & $13.6 \pm 3.3$ & $81.1 \pm 3.9$ & $603 \pm 28.9$ \\
2 & $26 / 6 / 13$ & $16: 00-18: 00$ & $287.5 \pm 17.0$ & $3.8 \pm 1.0$ & $70.7 \pm 3.4$ & $349.8 \pm 15.1$ \\
3 & $27 / 6 / 13$ & $09: 40-12: 15$ & $277.6 \pm 20.9$ & $4.2 \pm 1.4$ & $69.6 \pm 2.7$ & $354.1 \pm 11.1$ \\
4 & $27 / 6 / 13$ & $14: 20-17: 50$ & $275.1 \pm 24.5$ & $6.6 \pm 1.6$ & $72.6 \pm 5.4$ & $343.1 \pm 31.7$ \\
5 & $3 / 7 / 13$ & $10: 40-13: 00$ & $280.7 \pm 11.0$ & $6.3 \pm 1.3$ & $71.9 \pm 4.0$ & $366.1 \pm 7.2$ \\
6 & $4 / 7 / 13$ & $15: 20-16: 55$ & $240.7 \pm 11.3$ & $7.5 \pm 1.4$ & $72.5 \pm 4.5$ & $365.1 \pm 18.3$ \\
\hline
\end{tabular}
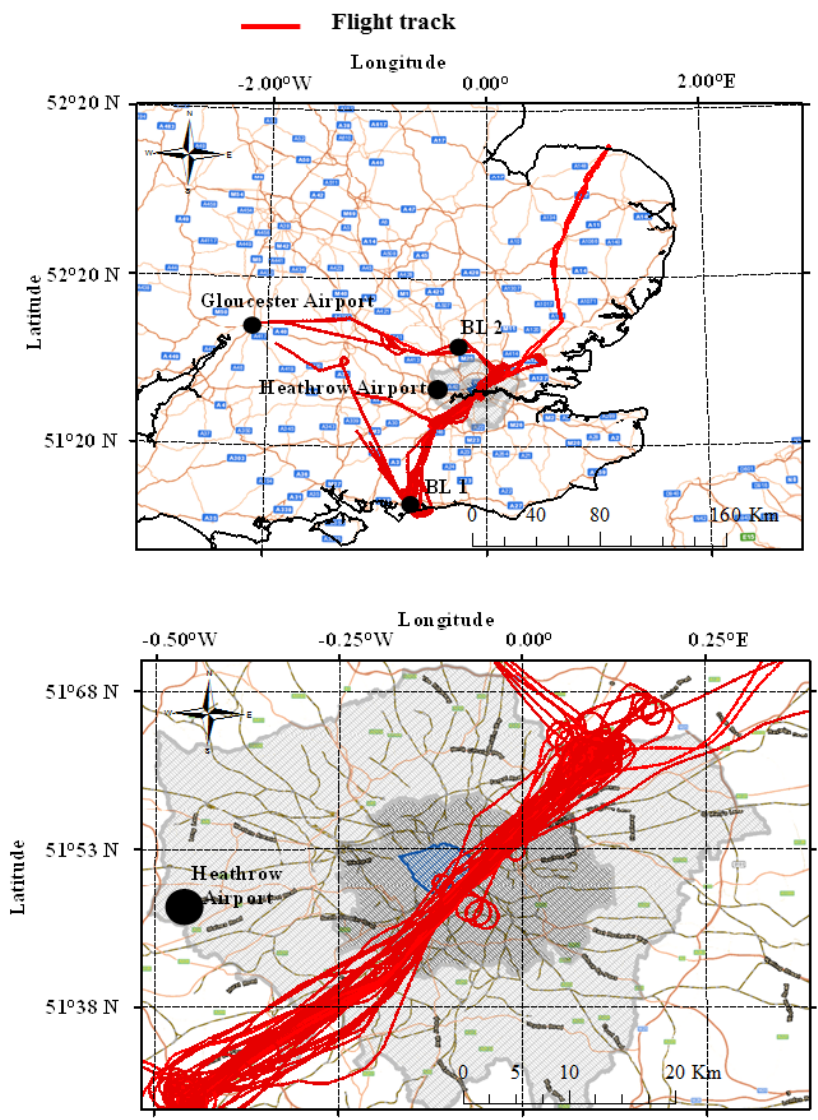

Figure 1. Top map shows all NERC Dornier 228 flights overlaid on UK transport map. Bottom map shows total flight legs across Greater London. Grey area: Greater London boundary; black area: inner London boundary; blue area: London CCZ.

tions were used. Briefly, before commencing the city transects, a spiral descent from 2500 to $350 \mathrm{~m}$ a.g.l was performed $70 \mathrm{~km}$ south of London (position BL 1, Fig. 1b). Similarly, immediately after completing the city transects, a spiral ascent from 350 to $2500 \mathrm{~m}$ was performed directly north of London (position BL 2, Fig. 1b). These manoeuvres were performed to determine the height of the BL before and after the flights.

\subsection{Meteorological and GPS sampling}

The core equipment on the aircraft consisted of an AircraftIntegrated Meteorological Measurement System (AIMMS20) turbulence probe (Aventech Research Inc.) mounted in an underwing pod. The instrument is capable of precisely defining the aircraft altitude and velocity to within fractions of $1 \mathrm{~s}^{-1}$ ) with a temperature and humidity measurement precision of approximately $1 \%$. This information is combined with fully compensated air-data measurements to compute wind speed with an accuracy of $0.5 \mathrm{kn}$ and a wind direction accuracy of $5-10^{\circ}$ (Beswick et al., 2008). The 3-D position of the aircraft was measured using an IPAS 20 (inertial-position and altitude system; Leica) at an accuracy of $0.05-0.3 \mathrm{~m}$. All variables were acquired at a data acquisition rate of $20 \mathrm{~Hz}$.

\section{$2.4 \quad \mathrm{NO}_{x}$ sampling}

$\mathrm{NO}_{x}$ was measured from the aircraft using a fast time resolution $(10 \mathrm{~Hz})$, high-sensitivity $\mathrm{NO}_{x}$ chemiluminescence system built by Air Quality Design, Inc. The instrument has a dual-channel architecture for independent quantification of $\mathrm{NO}$ and $\mathrm{NO}_{2}$. Each channel has a sample flow of $1.5 \mathrm{~L} \mathrm{~min}^{-1}$ to ensure the required fast response time. Both sample flows are continually humidified to ensure that any changes in ambient humidity do not change the instrument sensitivity due to quenching of the chemiluminescence by water vapour. A detailed review of a similar system is found in Lee et al. (2009); this system is a single/channel instrument which operates using the same principles as the Cape Verde Atmospheric Observatory. $\mathrm{NO}_{2}$ was quantified in a second channel by photolytic conversion to NO using blue light LED diodes centred at $395 \mathrm{~nm}$. The $395 \mathrm{~nm}$ wavelength has a specific affinity for $\mathrm{NO}_{2}$ photolytic conversion to $\mathrm{NO}$, giving high analyte selectivity within the channel. Recent work (Pollack et al., 2010) evaluated the relatively high $\mathrm{NO}_{2}$ affinity for the conversion of $\mathrm{NO}_{2}$ to $\mathrm{NO}$ using $395 \mathrm{~nm}$ blue light LEDs. They highlighted the low probability of other species within the gaseous chemical matrices, such as nitrous acid (HONO), being affected by the $395 \mathrm{~nm}$ light, thus in turn reducing possible non- $\mathrm{NO}_{2}$ species interference with the measurement. $\mathrm{NO}_{x}$ was then quantified by the ozonation of the subsequent 
total $\mathrm{NO}$ present in the reaction vessel after conversion with $\mathrm{NO}_{2}$ derived from the difference between $\mathrm{NO}_{x}$ and $\mathrm{NO}$ mixing ratios.

The instrument was calibrated by adding a small flow $(5 \mathrm{sccm})$ of a known NO concentration (5 ppmv - Air Liquide) to the ambient sample flow, resulting in around 10ppbv of NO. The conversion efficiency of the $\mathrm{NO}_{2}$ converter was measured during each calibration by gas phase titration of the $\mathrm{NO}$ to $\mathrm{NO}_{2}$ by the addition of $\mathrm{O}_{3} \cdot \mathrm{NO}_{2}$ mixing ratio data is corrected by using the measured $90 \%$ photolytic conversion efficiency. In-flight calibrations were always carried out above the boundary layer, thus ensuring low and stable background levels of $\mathrm{NO}_{x}$. Typically calibrations are carried out at the beginning and end of a flight, with sensitivities and conversion efficiency interpolated between the two and applied to all data. In this work, the $10 \mathrm{~Hz}$ data have been averaged to $1 \mathrm{~Hz}$, with detection limits for the $1 \mathrm{~Hz}$ data being $\sim 75$ pptv for $\mathrm{NO}$ and 100 pptv for $\mathrm{NO}_{2}$ and with approximate total errors at 1 ppbv being 10 and $15 \%$ for $\mathrm{NO}$ and $\mathrm{NO}_{2}$ respectively.

\subsection{Ozone sampling}

Ozone was quantified in situ, using a Thermo Scientific 49i UV absorption instrument generating data every $4 \mathrm{~s}$. A mercury lamp emitting UV light was used, with absorption at $254 \mathrm{~nm}$ being proportional to $\mathrm{O}_{3}$ concentration. The measurement uncertainty was estimated to be $\pm 0.8 \mathrm{ppbv}$.

\subsection{VOC sampling}

Benzene and toluene mixing ratios were determined simultaneously using an Ionicon (Innsbruck, Austria) highsensitivity proton transfer reaction mass spectrometer (PTRMS) fitted with a stainless-steel ringed drift tube $(9.6 \mathrm{~cm})$ and three Pfeiffer vacuum turbo-molecular pumps. This instrument has been described in detail elsewhere (Karl et al., 2009; de Gouw and Warneke, 2007; Hewitt et al., 2003; Hayward et al., 2002). Therefore, only instrument set-up, operation and flight modifications are outlined here. The instrument, normally housed in one cabinet, had been reengineered by the manufacturers into two racks suitable for mounting into the aircraft. To mitigate shock and vibration to the PTR-MS during flight, the instrument racks, mass spectrometer and MD4 diaphragm pump were individually shock-mounted using stainless-steel spring mountings (vibrachoc). A pressure controller was added (Bronkhorst), which regulates the inlet flow $(50-500 \mathrm{sccm})$ such that pressure upstream of the controller is maintained at a constant value. As a result the PTR-MS drift tube pressure is independent of fluctuations in ambient pressure caused by varying flight altitude. Ambient sample air was only exposed to heated $\left(70^{\circ} \mathrm{C}\right)$ Teflon and stainless-steel tubing, minimising memory effects, inlet losses and the build-up of impurities in the inlet system. Considerable efforts were made to pre- vent VOC contamination of the PTR-MS inlet during operation on the ground and during take-off. On the ground the PTR-MS inlet remained closed (and all sample tubing capped). Approximately $3 \mathrm{~h}$ before each flight the instrument voltages were switched on to allow for primary ion count stabilisation and instrument calibration. During this time dry zero-grade air (BOC Industrial gases, Manchester, UK) was purged through the zero-air generator and PTR-MS inlet in series to minimise instrument background and to prevent the build-up of contaminants. Immediately prior to take off, the sample flow was instantaneously switched to dry zerograde air contained in a $1 \mathrm{~L}$ silica-coated stainless-steel can (Thames Restek, UK) within the aircraft, which was then continuously sampled until the aircraft had reached an altitude of $2500 \mathrm{~m}$, allowing the PTR-MS to be fully operational during take-off.

VOC measurements were obtained at a sampling rate of $5 \mathrm{~Hz}$ and a repetition rate of $\sim 2 \mathrm{~Hz}$. In this work, the $2 \mathrm{~Hz}$ mixing ratio data have been averaged to $1 \mathrm{~Hz}$ for analysis. The target protonated masses and likely contributing compounds were $m / z 79$ (benzene) and $m / z 93$ (toluene). Additionally, both the primary ion count $m / z 21\left(\mathrm{H}_{3}^{18} \mathrm{O}^{+}\right)$, its first water cluster $\left(\mathrm{H}_{3}^{18} \mathrm{OH}_{2}^{18} \mathrm{O}^{+}\right)$at $m / z 39$ and $\mathrm{O}_{2}^{+}$at $\mathrm{m} / z 32$ were determined. PTR-MS drift tube pressure, temperature and voltage were held constant at $2.0 \mathrm{mbar}, 40^{\circ} \mathrm{C}$ and $480 \mathrm{~V}$ respectively, maintaining an $\mathrm{E} / \mathrm{N}$ ratio of approximately $110 \mathrm{Td}$. For flights at $\sim 360 \mathrm{~m}$ a.g.l, the $\mathrm{m} / \mathrm{z} 21$ primary ion count ranged between $(4$ and 7$) \times 10^{7}$ ion counts per second (cps), with an average of $6 \times 10^{7}$. Ion counts of $\mathrm{m} / \mathrm{z} 32$ ranged between $(0.8$ and 3$) \times 10^{6} \mathrm{cps}$, with an average of $2 \times 10^{6} \mathrm{cps}$, which represented $3 \%$ of the primary ion signal. Ion counts of $\mathrm{m} / z 39$ ranged between ( 1 and $5) \times 10^{6} \mathrm{cps}$ with an average of $3 \times 10^{6} \mathrm{cps}$, which represented $6 \%$ of the primary ion signal.

Toluene and benzene calibrations were carried out approximately $2 \mathrm{~h}$ prior to each flight using an dynamic dilution calibration system built in house. This involved the dynamic dilution of a 500 ppbv certified gas standard (Apel, Riemer) with humidity-controlled zero-grade air (BOC gases) to mixing ratios near typically observed levels. Zero-air humidity was calibrated over $20-80 \%$ RH in triplicate to assess humidity effects on sensitivity during the campaign. Benzene and toluene do not react with the hydrated hydronium ions generated at higher ambient air humidity within the PTR-MS drift tube (Warneke et al., 2001). To account for this humiditydependent PTR-MS sensitivity toward benzene and toluene, these compounds were normalised against the hydronium ion counts only. Typical instrument sensitivities observed during the campaign ranged between 380 and $480 \mathrm{icps} \mathrm{ppbv}^{-1}$ (6-8 normalised ion counts per second (ncps)) and 400 $600 \mathrm{icps} \mathrm{ppbv}^{-1}$ (6-9 ncps) for benzene and toluene respectively. Instrument uncertainties were $16 \pm 5$ and $21 \pm 9 \%$ for benzene and toluene respectively, calculated using the standard deviation of linear regression $(\mathrm{Sm})$ of pre-flight calibra- 
tions. Instrument limits of detection (LoDs) for $1 \mathrm{~Hz}$ averaged data were determined by the method outlined by Taipale and colleagues (Taipale et al., 2008) and were $13 \pm 8$ and $18 \pm 11$ pptv for benzene and toluene respectively.

During flights, ambient air was sampled from the forwardfacing stainless-steel isokinetic inlet along a heated $\left(70^{\circ} \mathrm{C}\right)$ $5 \mathrm{~m}$ Teflon tube $\left(0.25^{\prime \prime}\right.$ o.d., $0.2^{\prime \prime}$ i.d.) pumped by a stainless-steel diaphragm pump (Millipore) at a flow rate of $22 \mathrm{~L} \mathrm{~min}^{-1}$. A portion of this ambient air $(\sim 300 \mathrm{sccm})$ was diverted into the pressure-controlled inlet of the PTRMS instrument such that the overall delay time was $<3 \mathrm{~s}$. To determine blank VOC mixing ratios, the remaining ambient air was purged into a custom-built zero-air generator which consisted of a $3 / 8^{\prime \prime}$ stainless-steel tube packed with $1 \mathrm{~g}$ of platinum coated quartz wool (Elemental Microanalysis), which efficiently removes VOCs (de Gouw et al., 2004). The zero-air generator was operated at $350{ }^{\circ} \mathrm{C}$ and $30 \mathrm{psi}$ for the duration of the flights to maintain optimal operating conditions. The catalytic converter does not remove water vapour from the sample stream, which is of particular importance as the instrument response from background impurities may depend upon sample air humidity. During flights, zero air was periodically back-flushed through the inlet system to determine instrument background.

\subsection{LAQN ground monitoring sites}

Data were obtained from three LAQN ground-level monitoring sites for comparative purposes. These were

- Marylebone Road (Westminster), an urban kerbside site in a street canyon, situated $1.5 \mathrm{~m}$ from the kerb of a frequently congested six-lane road, the A501 $\left(51.5225^{\circ} \mathrm{N}\right.$, $\left.0.1546^{\circ} \mathrm{W}\right)$.

- Horseferry Road (Westminster), an urban background monitoring station located within an area of mixed commercial and residential buildings $\left(51.4947^{\circ} \mathrm{N}\right.$, $\left.0.1319^{\circ} \mathrm{W}\right)$. The nearest road is the B323 Horseferry Road approximately $17 \mathrm{~m}$ north of the station.

- Greenwich-Eltham (Eltham), a suburban background site situated in Greenwich within an education centre $\left(51.4526^{\circ} \mathrm{N}, 0.0708^{\circ} \mathrm{E}\right)$. The site is approximately $25 \mathrm{~m}$ from the nearest road, the A210 Bexley Road. The surrounding area consists of trees, grassland, recreational areas and suburban housing.

These sites all monitor $\mathrm{NO}, \mathrm{NO}_{2}$ and $\mathrm{NO}_{x}$ at an hourly resolution and $\mathrm{O}_{3}$ at a $15 \mathrm{~min}$ resolution. However, only the Westminster-Marylebone Road and Greenwich-Eltham monitoring sites monitor benzene and toluene at an hourly resolution. The locations are shown in Fig. S1 in the Supplement.

\section{Results}

\subsection{Intercomparison of WAS TD-GC-FID and PTR-MS}

To compare the volume mixing ratios obtained with the onboard PTR-MS with those measured by gas chromatography with flame ionisation detection (GC-FID), whole-air canister sampling (WAS) was conducted twice per flight using silica coated stainless-steel cans (Thames Restek, UK) with subsequent GC-FID analysis for benzene and toluene (Hopkins et al., 2003, 2009). The WAS system avoids possible artefact formation or analyte loss that may occur on adsorbents if a pre-concentration sampling system is used (Cao and $\mathrm{He}$ witt, 1993, 1994a, b). Previous ground observations in several urban environments have shown generally good agreement between benzene and toluene mixing ratios obtained during PTR-MS and GC-FID intercomparisons (Rogers et al., 2006; Warneke et al., 2001). However, Jobson et al. (2010) suggest a $16 \%$ overestimation of benzene mixing ratios determined by PTR-MS compared to a GC method; this is attributed to the fragmentation of higher alkyl benzenes (e.g. ethyl benzene). An intercomparison of the two sampling methods showed excellent agreement within uncertainty and, in particular, suggested that the PTR-MS demonstrated minimal bias due to the fragmentation of higher alkyl benzenes during this study, as shown Fig. S2 in the Supplement. Hence the PTR-MS signal obtained at $m / z 79$ is assumed to be due to benzene alone.

\subsection{Interpretation of temporal trace gas profiles}

Mixing ratios of $\mathrm{VOCs}, \mathrm{NO}_{x}, \mathrm{O}_{3}$ and $\mathrm{NO} / \mathrm{NO}_{2}$ ratios from 27 individual flight transects of Greater London during RF 2-6 were averaged to assess how they changed with respect to time over the 7 days of flights (Table 2). As shown in Fig. 2, $\mathrm{NO}_{x}$, benzene and toluene mixing ratios followed the typical diurnal pattern previously observed in urban areas with maxima measured during morning rush hours and a minimum measured at approximately 16:00-18:00 local time when $\mathrm{O}_{3}$ reaches its maximum (Langford et al., 2010; Marr et al., 2013). The highest $\mathrm{NO}_{x}$ and VOC mixing ratios were observed in the morning at 10:30 local time $\sim 40$ ppbv $\mathrm{NO}_{x}, \sim 350$ pptv toluene and $\sim 200$ pptv benzene at $360 \pm 10 \mathrm{~m}$ a.g.l. - when emissions from traffic-related sources are highest and the mixing height relatively low. Mixing ratios decreased throughout the morning, probably due to a combination of boundary layer development leading to dilution and increasing $\mathrm{OH}$ oxidation leading to enhanced chemical removal, with mixing ratios stabilising later in the day at 10-20 ppbv $\mathrm{NO}_{x}$ and between 90 and 150 pptv benzene and toluene. Variations in the $\mathrm{O}_{3}$ mixing ratio are generally attributed to photochemical production in the mixing layer, with some contribution from entrainment from the free troposphere (Dueñas et al., 2002). In London, the low $\mathrm{O}_{3}$ 


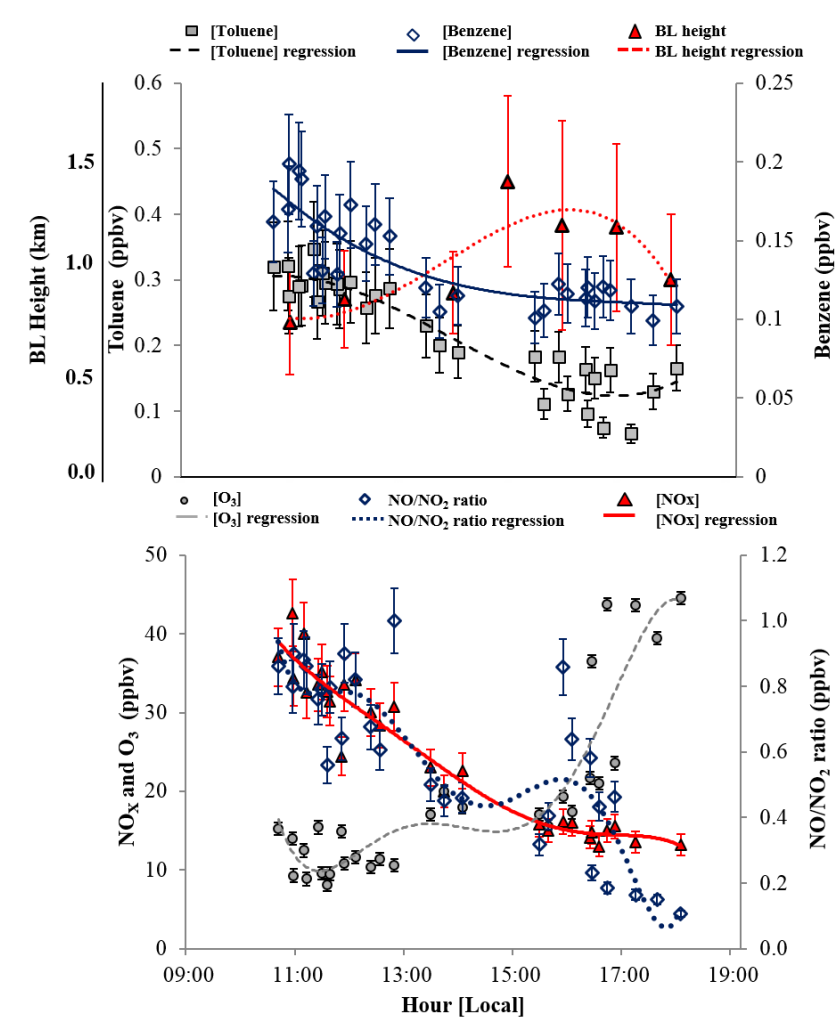

Figure 2. Top: time series of averaged benzene and toluene concentrations observed at $360 \pm 10 \mathrm{~m}$ a.g.l. during RF 2-6. Bottom: time series of averaged $\mathrm{NO} / \mathrm{NO}_{2}$ ratios and $\mathrm{O}_{3}$ and $\mathrm{NO}_{x}$ concentrations during RF 2-6.

morning mixing ratios were attributed to the destruction of $\mathrm{O}_{3}$ by rapid titration with $\mathrm{NO}$, which is emitted during the morning rush hour and is highest during the morning. As the day progresses, sunlight intensity becomes higher, increasing the radical concentration and hence the $\mathrm{NO}$ to $\mathrm{NO}_{2}$ oxidation rate from the reaction of NO with peroxy radicals. Subsequent photolysis of $\mathrm{NO}_{2}$ leads to increased $\mathrm{O}_{3}$ throughout the day (Pudasainee et al., 2010), with the rate of $\mathrm{O}_{3}$ production being a function of $\mathrm{NO}_{x}$ and VOC levels as well as sunlight intensity.

Recent studies of annually averaged daily VOC mixing ratios in London from the $191 \mathrm{~m}$ high BT (British Telecom) Tower have shown that benzene and toluene mixing ratios typically display two daytime maxima: one occurring around 09:00 and a second, larger peak occurring between 18:00 and 21:00 local time and coinciding with morning and evening peak traffic periods (Langford et al., 2010; Lee et al., 2015). $\mathrm{NO}_{x}$ mixing ratios are highest when traffic flow peaks, with higher $\mathrm{O}_{3}$ mixing ratios corresponding to lower $\mathrm{NO}_{x}$ mixing ratios and vice versa during a $24 \mathrm{~h}$ period (Im et al., 2013; Lu and Wang, 2004; Mazzeo et al., 2005). This indicates that patterns in VOC and $\mathrm{NO}_{x}$ emission have a larger effect on observed mixing ratios in the boundary layer than do boundary layer dynamics.

\subsection{Horizontal spatial distribution of VOCs and $\mathrm{NO}_{x}$ mixing ratios}

The predominant wind directions observed during the flights were north-westerly (RF 2-6), perpendicular to the flight transects (Table 1). Research flights 2-6 were used to provide a cross section of pollutant mixing ratios across London. The relative spatial distribution of $\mathrm{VOC}$ and $\mathrm{NO}_{x}$ mixing ratios across greater London during these flights was superficially consistent, with average mixing ratios for each flight leg only changing temporally (Fig. 2); hence, only RF 5 is shown here.

Figures 3 and 4 show $1 \mathrm{~km}$ averaged mixing ratios of VOCs and $\mathrm{NO}_{x}$ respectively during RF 5 in relation to latitude across Greater London. Both VOC and $\mathrm{NO}_{x}$ mixing ratios are significantly higher in inner London. For all compounds the highest mixing ratios were observed within inner London at $360 \pm 10 \mathrm{~m}$ a.g.l., particularly directly downwind of the London CCZ. Average mixing ratios observed within inner London were $0.20 \pm 0.05,0.28 \pm 0.07$, $13.2 \pm 8.6,21.0 \pm 7.3$ and $34.3 \pm 15.2 \mathrm{ppbv}$ for benzene, toluene, $\mathrm{NO}, \mathrm{NO}_{2}$ and $\mathrm{NO}_{x}$ respectively. Mixing ratios for benzene, toluene, $\mathrm{NO}, \mathrm{NO}_{2}$ and $\mathrm{NO}_{x}$ for all flights are shown in Table 2.

Vehicular emissions are considered to be an important source of VOCs and $\mathrm{NO}_{x}$ in Greater London (Langford et al., 2010; Lee et al., 2015). Toluene has a shorter atmospheric lifetime than benzene due to faster photochemical removal by $\mathrm{OH}$ (rate constants of $1.45 \pm 0.06 \times 10^{12} k \mathrm{~cm}^{3}$ molecule $^{-1} \mathrm{~s}^{-1}$ and $6.03 \pm 0.17 \times 10^{12} k \mathrm{~cm}^{3}$ molecule ${ }^{-1} \mathrm{~s}^{-1}$ for benzene and toluene respectively at $298 \mathrm{~K}$; Ohta and Ohyama, 1985); thus, the $\mathrm{T} / \mathrm{B}$ ratio can indicate the photochemical age of the pollution carried by air masses (Warneke et al., 2001; Atkinson, 2000). Very close to the source of emissions (e.g. at the kerbside), the VOC mixing ratios should be similar to those in the emissions themselves. As toluene is more rapidly removed by oxidation, the $\mathrm{T} / \mathrm{B}$ ratio progressively decreases as air is transported over longer distances away from the source. Vehicular exhaust emission ratios from combustion during transient engine operation are dependent on gasoline composition but within Europe typically yield T/B ratios of between 1.25 and $2.5 \mathrm{ppbv} p p b v^{-1}$ (Heeb et al., 2000). The introduction of catalytic converters to vehicular exhausts has been shown to significantly decrease this $\mathrm{T} / \mathrm{B}$ ratio; this is attributed to the reduced catalytic conversion efficiency for benzene with respect to alkylated benzenes (Heeb et al., 2000). Hence, observed ambient T/B mixing ratios will be a product of the photochemical age of the air mass since emission, vehicular fleet composition, gasoline composition and the amount of vehicles using catalytic converters.

Recent long-term VOC measurements made at two ground-level sites in central London dominated by traffic sources - Marylebone Road and North Kensington (Valach et al., 2014) - showed average T/B ratios of 
Table 2. Summary of mixing ratios (ppbv) observed over inner London during campaign.

\begin{tabular}{|c|c|c|c|c|c|c|}
\hline & $\mathrm{RF} 1$ & RF2 & RF3 & RF4 & RF5 & RF6 \\
\hline \multicolumn{7}{|l|}{ Benzene } \\
\hline Mean & 0.08 & 0.09 & 0.22 & 0.10 & 0.20 & 0.10 \\
\hline Median & 0.07 & 0.09 & 0.15 & 0.09 & 0.19 & 0.10 \\
\hline $\mathrm{SD}$ & 0.06 & 0.05 & 0.06 & 0.05 & 0.05 & 0.05 \\
\hline 5th percentile & 0.01 & 0.03 & 0.06 & 0.03 & 0.09 & 0.03 \\
\hline 95th percentile & 0.178 & 0.20 & 0.27 & 0.17 & 0.22 & 0.19 \\
\hline$N$ & 16500 & 13900 & 14100 & 2560 & 7620 & 11260 \\
\hline \multicolumn{7}{|l|}{ Toluene } \\
\hline Mean & 0.17 & 0.12 & 0.28 & 0.15 & 0.28 & 0.12 \\
\hline Median & 0.16 & 0.12 & 0.27 & 0.15 & 0.25 & 0.11 \\
\hline SD & 0.07 & 0.08 & 0.11 & 0.07 & 0.07 & 0.09 \\
\hline 5th percentile & 0.08 & 0.06 & 0.05 & 0.05 & 0.12 & 0.01 \\
\hline 95th percentile & 4.34 & 0.26 & 0.39 & 0.32 & 0.38 & 0.28 \\
\hline$N$ & 16500 & 13900 & 14100 & 2560 & 7620 & 11260 \\
\hline \multicolumn{7}{|l|}{ NO } \\
\hline Mean & 3.83 & 2.06 & 17.46 & 8.81 & 13.20 & 4.80 \\
\hline Median & 3.46 & 2.44 & 16.19 & 7.76 & 12.43 & 3.41 \\
\hline $\mathrm{SD}$ & 2.16 & 2.50 & 7.42 & 1.88 & 8.60 & 3.61 \\
\hline 5th percentile & 1.06 & 0.70 & 3.49 & 1.91 & 1.98 & 1.23 \\
\hline 95th percentile & 7.82 & 7.94 & 25.71 & 7.44 & 21.33 & 12.17 \\
\hline$N$ & 82500 & 69500 & 70500 & 12800 & 38100 & 56300 \\
\hline \multicolumn{7}{|l|}{$\mathrm{NO}_{2}$} \\
\hline Mean & 15.19 & 11.99 & 22.95 & 18.64 & 21.02 & 12.17 \\
\hline Median & 13.59 & 11.44 & 26.54 & 22.13 & 20.23 & 10.65 \\
\hline SD & 6.10 & 8.29 & 13.17 & 7.89 & 6.38 & 7.31 \\
\hline 5th percentile & 7.56 & 7.91 & 11.45 & 10.21 & 6.03 & 3.65 \\
\hline 95th percentile & 26.49 & 31.90 & 52.13 & 35.08 & 25.97 & 19.60 \\
\hline$N$ & 82500 & 69500 & 70500 & 12800 & 38100 & 56300 \\
\hline \multicolumn{7}{|l|}{$\mathrm{NO}_{x}$} \\
\hline Mean & 19.02 & 16.05 & 40.41 & 27.45 & 34.3 & 16.97 \\
\hline Median & 17.49 & 17.91 & 36.02 & 26.78 & 32.40 & 15.95 \\
\hline SD & 7.96 & 10.39 & 19.87 & 9.67 & 15.20 & 8.50 \\
\hline 5th percentile & 8.71 & 9.00 & 15.53 & 12.16 & 9.35 & 5.20 \\
\hline 95 th percentile & 33.62 & 39.36 & 76.08 & 42.69 & 44.54 & 30.04 \\
\hline$N$ & 82500 & 69500 & 70500 & 12800 & 38100 & 56300 \\
\hline
\end{tabular}

$1.6 \pm 0.3 \mathrm{ppbv} \mathrm{ppbv}^{-1}$ and $1.8 \pm 0.3 \mathrm{ppbv} \mathrm{ppbv}^{-1}$ respectively. These $\mathrm{T} / \mathrm{B}$ ratios are similar to the average $\mathrm{T} / \mathrm{B}$ concentration ratio of $1.8 \pm 0.5 \mathrm{ppbv} \mathrm{ppbv}^{-1}$ observed within inner London in this study, where traffic sources are likely to be the highest (Fig. 3). Average T/B concentration ratios in suburban (latitude 51.30-51.35 ${ }^{\circ}$ ) and south-western Greater London (latitude $51.35-51.42^{\circ}$ ) were $1.1 \pm 0.3 \mathrm{ppbv} \mathrm{ppbv}^{-1}$ and $1.3 \pm 0.4 \mathrm{ppbv} \mathrm{ppbv}^{-1}$ respectively. This could be interpreted as increasing air mass age from emission and suggests that the sources of benzene and toluene in these regions are likely the product of local emission and horizontal advection from inner London.

Linear regression analysis between $\mathrm{NO}, \mathrm{NO}_{2}, \mathrm{NO}_{x}$, benzene and toluene mixing ratios yielded correlation coefficients $\left(R^{2}\right)$ ranging between 0.12 and 0.64 . The weakest linear regressions were observed between toluene and NO $\left(R^{2}=0.12, n=7500\right)$ and benzene and NO $\left(R^{2}=0.14\right.$, $n=6500$ ) (not shown). The strongest linear regressions were observed between toluene and benzene $\left(R^{2}=0.51\right.$, $n=6500)$ and toluene and $\mathrm{NO}_{2}\left(R^{2}=0.64, n=7500\right)$ (Fig. 5). A strong covariance exists between benzene, toluene 


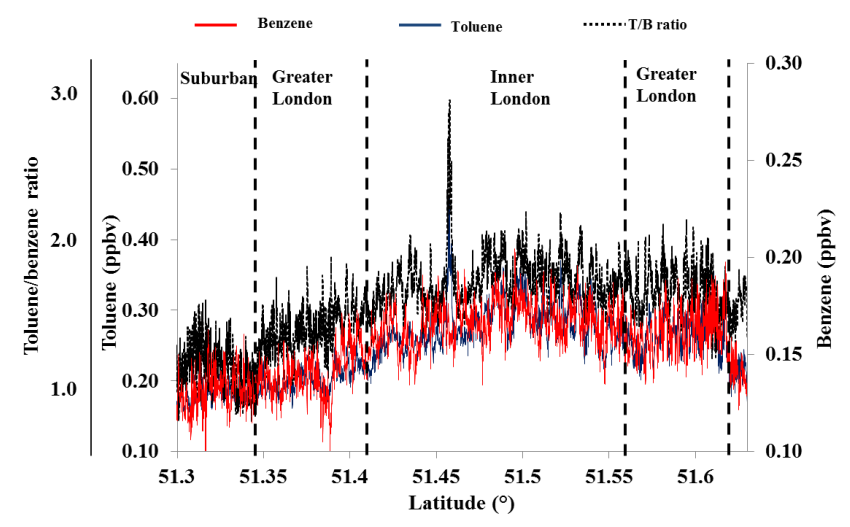

Figure 3. City cross section of $1 \mathrm{~km}$ averaged benzene/toluene mixing ratios and $\mathrm{T} / \mathrm{B}$ instantaneous ratios $\left(\mathrm{ppbvppbv}^{-1}\right)$ at $360 \pm 10$ m a.g.l. across Greater London during RF 5.

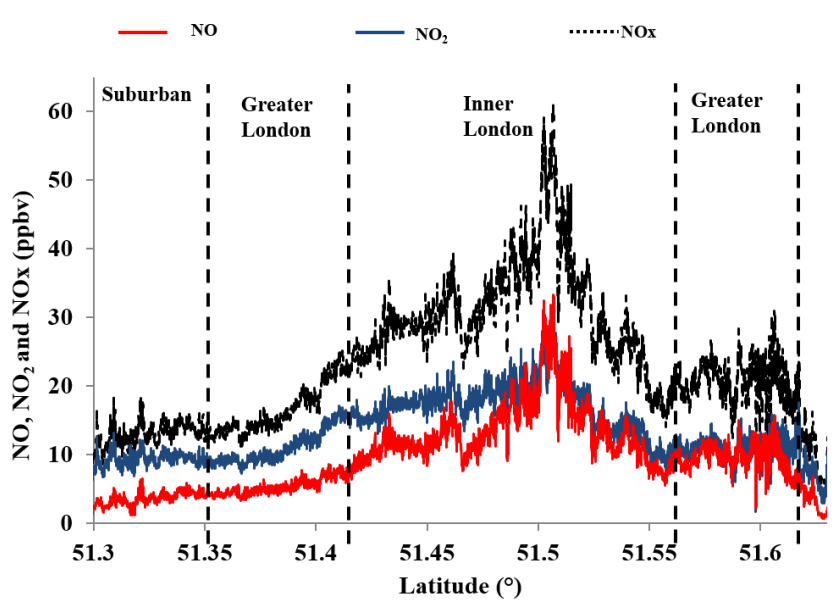

Figure 4. City cross section of $1 \mathrm{~km}$ averaged $\mathrm{NO}, \mathrm{NO}_{2}$ and $\mathrm{NO}_{x}$ mixing ratios across Greater London at $360 \pm 10 \mathrm{~m}$ a.g.l. during RF 5.

and $\mathrm{NO}_{2}$ mixing ratios, indicating that these compounds potentially share the same or co-located sources within the Greater London area, most likely vehicular emission. However the measured $\mathrm{NO}_{2} / \mathrm{NO}$ concentration ratio at $360 \mathrm{~m}$ a.g.l is likely to be dominated by photochemistry rather than emission sources (Atkinson et al., 2000).

Figure 5 also suggests a secondary-source contribution to toluene that is not shared with $\mathrm{NO}_{2}$ or benzene and hence is not related to traffic emissions. This secondary source is localised by a discrete peak in observed toluene in SE London within the borough of Lambeth (latitude $51.455^{\circ}$, longitude $-0.141^{\circ}$ ). This was observed during three of the seven flight transects in which toluene mixing ratios at $360 \pm 10 \mathrm{~m}$ a.g.l. increased from $0.25 \mathrm{ppbv}$ to $0.6 \mathrm{ppbv}$ with a $\mathrm{T} / \mathrm{B}$ ratio of up to $3 \mathrm{ppbv} \mathrm{ppbv}^{-1}$, as seen in Fig. 3. Toluene has numerous anthropogenic sources including evaporative fuel losses, industrial solvents, paint thinners and the manufacturing of ink and paints. Direct toluene emissions from industri-

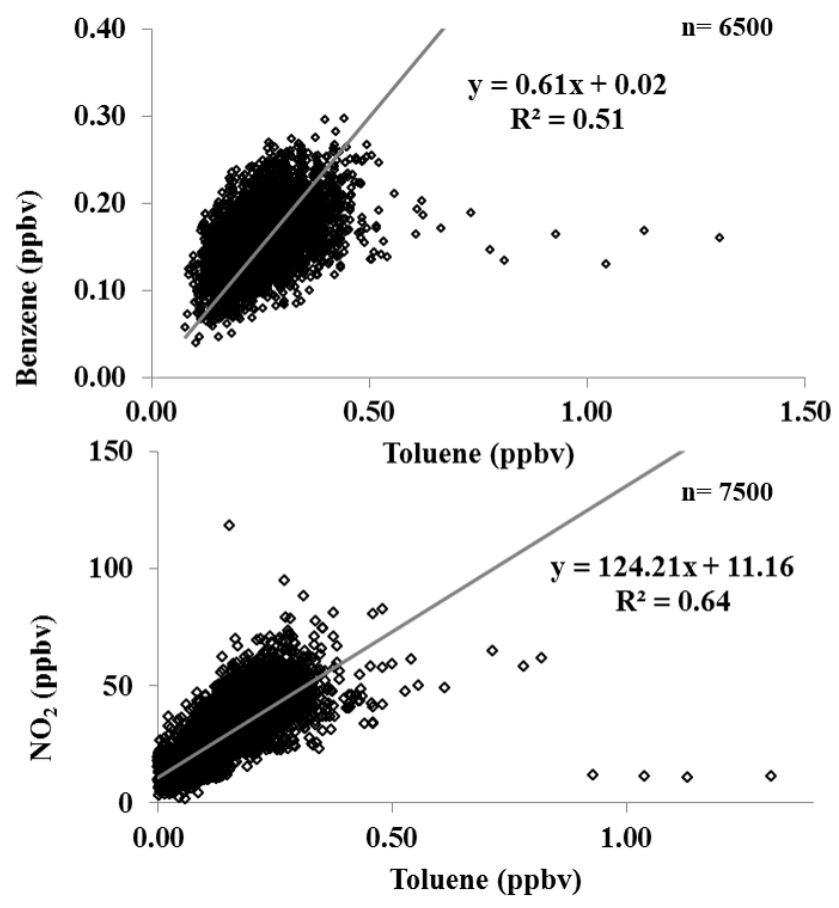

Figure 5. Top: linear regression analysis of benzene/toluene mixing ratios at $360 \pm 10 \mathrm{~m}$ a.g.l. during RF 5. Bottom: linear regression analysis of $\mathrm{NO}_{2}$ / toluene mixing ratios at $360 \pm 10 \mathrm{~m}$ a.g.l. during RF 5.

alised areas in Mexico city with T/B ratios of up to 8.5$12.5 \mathrm{ppbv} \mathrm{ppbv}^{-1}$ have previously been reported (Karl et al., 2009). In the absence of any identifiable industrialised areas upwind of the region of high $\mathrm{T} / \mathrm{B}$ ratios in Lambeth, this peak is possibly due to the horizontal advection of industrial emissions from outside of London or to some unidentified localised source of toluene.

The influence of $\mathrm{NO}_{x}$ and VOC emission from London Heathrow Airport (LHA) during this study was investigated with plume dispersion modelling using the NOAA Hybrid Single-Particle Lagrangian Integrated Trajectory (HYSPLIT) model. The model isolates the region of the flight track influenced by potential pollutant outflow from LHA during the flight. Four-hour averaged forward dispersion forecasting from LHA was modelled for RF1 and RF5 between 14:0016:00 and 09:00-12:00 local time respectively. The lower and upper limits of the averaged dispersion layer were 300 and $400 \mathrm{~m}$ a.g.l., similar to the measured average flight altitudes during these flights. During RF1 and RF 5 the transport time from LHA to the flight transect was approximately 25-50 min, calculated from the average observed horizontal wind speed and the $\sim 20 \mathrm{~km}$ downwind distance (Fig. 6).

Figure 6 shows the region of flight transects which were influenced by LHA outflow (51.39-51.45 latitude). On entering the LHA outflow plume, $\mathrm{NO}_{x}$ mixing ratios at $360 \pm 10 \mathrm{~m}$ a.g.l. during both RF1 and RF5 were observed to double, increasing from $\sim 15$ to $30 \mathrm{ppbv}$, suggesting a strong 


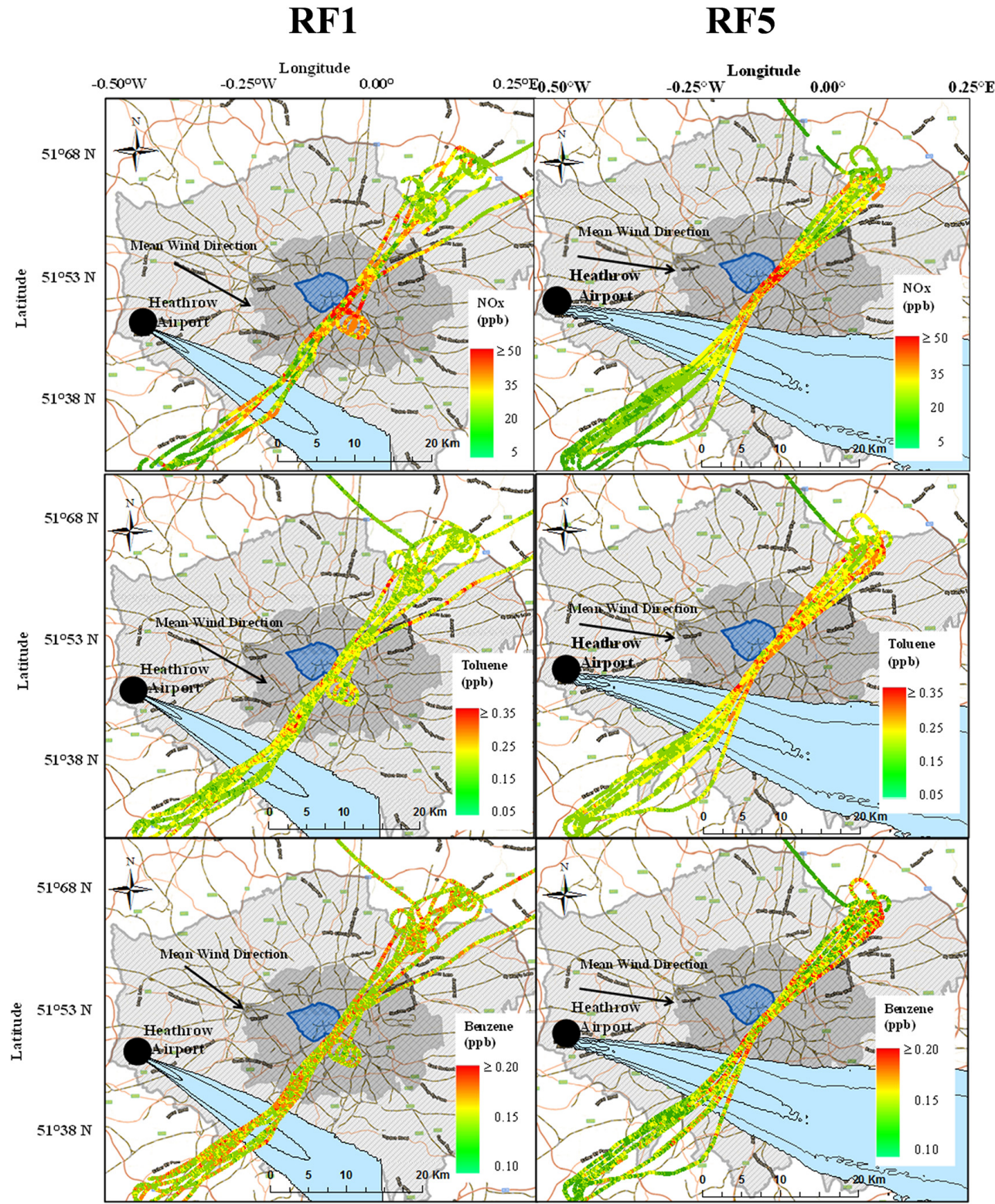

Figure 6. Top: $\mathrm{NO}_{x}$ concentration data (7 m resolved at $360 \pm 10 \mathrm{~m}$ a.g.1.) during RF1 (left) and RF5 (right) overlaid on UK transport map. Middle: Benzene concentration data (35 m resolved at $360 \pm 10 \mathrm{~m}$ a.g.l.) during RF 1 (left) and RF5 (right) overlaid on UK transport map. Bottom: Toluene concentration data (35 m resolved at $360 \pm 10 \mathrm{~m}$ a.g.l.) during RF1 (left) and RF5 (right) overlaid on UK transport map. Grey area: Greater London boundary; black area: inner London boundary; dark blue area: London CCZ; light blue area: $4 \mathrm{~h}$ averaged HYSPLIT dispersion trajectory.

$\mathrm{NO}_{x}$ source. As shown in Fig. 4 for RF5, the $\mathrm{NO} / \mathrm{NO}_{2}$ ratio also gradually increased across the plume from 0.5 up to $0.8 \mathrm{ppbv}_{\mathrm{ppbv}}{ }^{-1}$, which is consistent with previous studies that have found higher NO mixing ratios in aircraft exhaust (Spicer et al., 1994; Schäfer et al., 2000). Toluene and benzene mixing ratios showed a negligible increase from $\sim 0.20$ to 0.26 and $\sim 0.15$ to 0.18 ppbv at $360 \pm 10 \mathrm{~m}$ a.g.l. across the plume respectively, with $\mathrm{T} / \mathrm{B}$ ratios of 1.5 $1.7 \mathrm{ppbv} \mathrm{ppbv}^{-1}$ indicative of vehicular exhaust emission as the dominant VOC source. Previous ground observations
(Carslaw et al., 2006) at LHA suggested that approximately $27 \%$ of the annual mean $\mathrm{NO}_{x}$ and $\mathrm{NO}_{2}$ were due to airport operations at the airport boundary. At background locations 2-3 km downwind of the airport, they estimated the upper limit of the airport contribution to be less than $15 \%$. Our measurements are in qualitative agreement with this study, suggesting that even though Heathrow is an important emission source of $\mathrm{NO}_{x}$, observed mixing ratios of $\mathrm{NO}_{x}$ close to the airport are dominated by road traffic sources. As LHA was $\sim 20 \mathrm{~km}$ upwind of the flight transects, our observed 
mixing ratios are likely to be heavily influenced by emissions during advection from LHA to the measurement locations and, as such, conclusions drawn from this data are tentative.

\subsection{Interpretation of vertical trace gas profiles}

To date, the influence of vertical transport on the distribution of trace gases in the urban boundary layer has primarily been studied with respect to vertical profiles of ozone, which are typically obtained with in situ instruments mounted on tethered balloons (Beyrich et al., 1996; Güsten et al., 1998; Newchurch et al., 2003). Vertical profiling of VOCs, NO, $\mathrm{NO}_{2}$ and $\mathrm{NO}_{x}$ has also been studied using a combination of in situ measurements from tethered balloons and groundbased differential optical absorption spectroscopy (DOAS) over several American (Wang et al., 2003; Stutz et al., 2004; Velasco et al., 2008; Hu et al., 2012) and European cities (Glaser et al., 2003). To the authors' knowledge, the work herein represents the first vertical boundary layer profiling of both VOCs and $\mathrm{NO}_{x}$ species using research aircraft over a European city.

Vertical profiling of VOCs, $\mathrm{NO}_{x}$ and $\mathrm{O}_{3}$ above Greater London in this study was conducted during RF 1 on 24 June 2013 between the hours of 17:00 and 18:00 local time. Vertical profiling consisted of three sequentially stacked flights conducted at $350 \mathrm{~m}$ a.g.l. (17:00-17:20), $510 \mathrm{~m}$ a.g.l. (17:2017:40) and $650 \mathrm{~m}$ a.g.l. (17:40-18:00). The trace gas mixing ratios observed at each altitude were then averaged along the $\sim 35 \mathrm{~km}$ flight path over Greater London. These concentration profiles were then compared with hourly averaged upwind LAQN kerbside measurements made at 17:00 local time at the Marylebone Road air quality monitoring station to assess how trace gas mixing ratios change vertically from the street canyon to above the urban canopy. At the flight legs' closes point, they were $\sim 6 \mathrm{~km}$ downwind of the Marylebone Road measurement site. During RF 1, a predominantly northwesterly wind direction was observed, with a mean wind direction and wind speed of $285.9 \pm 17.1^{\circ}$ and $13.6 \mathrm{~m} \mathrm{~s}^{-1}$ respectively. Hence, the vertical concentration profiles observed represent a composite of local emission and horizontal advection of the Greater London region.

Figure 7 shows the comparison between the measured trace gas concentration profiles over Greater London and the Marylebone Road kerbside measurements. The measured concentration distributions of both benzene $(0.15 \pm 0.01 \mathrm{ppbv})$ and toluene $(0.16 \pm 0.01 \mathrm{ppbv})$ and their corresponding T / $\mathrm{B}$ ratio $\left(1.1 \pm 0.3 \mathrm{ppbv}_{\mathrm{ppbv}}{ }^{-1}\right)$ were vertically uniform with increasing altitude, suggesting rapid mixing between 350 and $650 \mathrm{~m}$. In this case VOC losses due to reaction with the $\mathrm{OH}$ radical are evidently too slow to produce observable concentration gradients in the vertical distribution. This suggests that turbulence mixes the species up to $650 \mathrm{~m}$ a.g.l. much faster than the $\mathrm{OH}$ radical depletes them. Over urban areas turbulence is promoted throughout the day due to thermal forcing produced by the urban energy balance (Velasco et al., 2008).

Both $\mathrm{NO}$ and $\mathrm{NO}_{2}$ show a large decrease in the mixing ratios of measurements at the kerbside and at $360 \pm 10 \mathrm{~m}$ a.g.l. (43 and $4.4 \mathrm{ppbv}$ for NO respectively and 28 and $17 \mathrm{ppbv}$ for $\mathrm{NO}_{2}$ ). In contrast to $\mathrm{NO}$ and $\mathrm{NO}_{2}, \mathrm{O}_{3}$ measurements were lowest at the kerbside site: $17 \mathrm{ppb}$, increasing to $32 \mathrm{ppbv}$ at $360 \pm 10 \mathrm{~m}$ a.g.l. The daytime vertical profiles of $\mathrm{NO}, \mathrm{NO}_{2}$ and $\mathrm{O}_{3}$ are due to a combination of turbulent mixing and three main simultaneous competing effects:

- the chemical production of $\mathrm{NO}_{2}$ by $\mathrm{NO}$ titration with $\mathrm{O}_{3}$ and $\mathrm{RO}_{2}$, causing higher $\mathrm{NO}_{2}$ and lower $\mathrm{O}_{3}$ mixing ratios closer to the surface due to higher surface NO mixing ratios;

- photochemical production of $\mathrm{NO}$ and $\mathrm{O}_{3}$ from $\mathrm{NO}_{2}$ and subsequent $\mathrm{O}_{3}$ destruction;

- $\mathrm{NO}_{2}$ and ozone dry deposition processes which dominate closer to the surface (Wesely and Hicks, 2000).

The vertical profiles of $\mathrm{NO}_{x}$ and $\mathrm{O}_{3}$ are superficially anticorrelated with altitude. The observed $\mathrm{O}_{3}$ profiles, with lower values close to the ground and higher values aloft, agree in their general behaviour with other observations (Beyrich et al., 1996; Glaser et al., 2003; Güsten et al., 1998) The vertical profiles of $\mathrm{O}_{3}$ and $\mathrm{O}_{x}$ (the sum of $\mathrm{O}_{3}$ and $\mathrm{NO}_{2}$ ) show the importance of $\mathrm{NO}$ emission for $\mathrm{O}_{3}$ depletion, with reduced surface $\mathrm{O}_{3}$ mixing ratios closer to the ground largely compensated for by a corresponding increase in $\mathrm{NO}_{2}$. As a result, $\mathrm{O}_{x}$ exhibits a very uniform vertical concentration between 350 and $650 \mathrm{~m}$ a.g.l. However, $\mathrm{O}_{x}$ mixing ratios are reduced at ground level, possibly due to enhanced deposition in proximity to the surface.

\subsection{Comparison of airborne measurements with LAQN ground sites}

Data obtained from three LAQN air quality ground monitoring stations located in three typical urban environments (urban kerbside: Marylebone Road; urban background: Westminster-Horseferry Road; and suburban background: Greenwich-Eltham) were compared to airborne mixing ratios at $360 \pm 10 \mathrm{~m}$ a.g.l. to assess how $\mathrm{O}_{3}$ and its precursors are distributed across the city. Dispersion modelling using the NOAA HYSPLIT model was used to highlight regions of the flight track most influenced by pollutant outflow from each of the ground monitoring stations. Briefly, $4 \mathrm{~h}$ averaged forward and reverse dispersion forecasting was modelled for Marylebone Road, Westminster and Eltham during flights with a prevailing north-westerly wind direction (RF 1, RF4-6, Table 1). RF 2 and 3 were not used in the comparison due to low observed wind speeds $\left(<5 \mathrm{~m} \mathrm{~s}^{-1}\right)$. The lower and upper limits of the averaged dispersion layer were 300 $400 \mathrm{~m}$ a.g.l., similar to the measured average flight altitude of $360 \pm 10$ m a.g.l. during RF 1 and RF4-6. Airborne mixing 

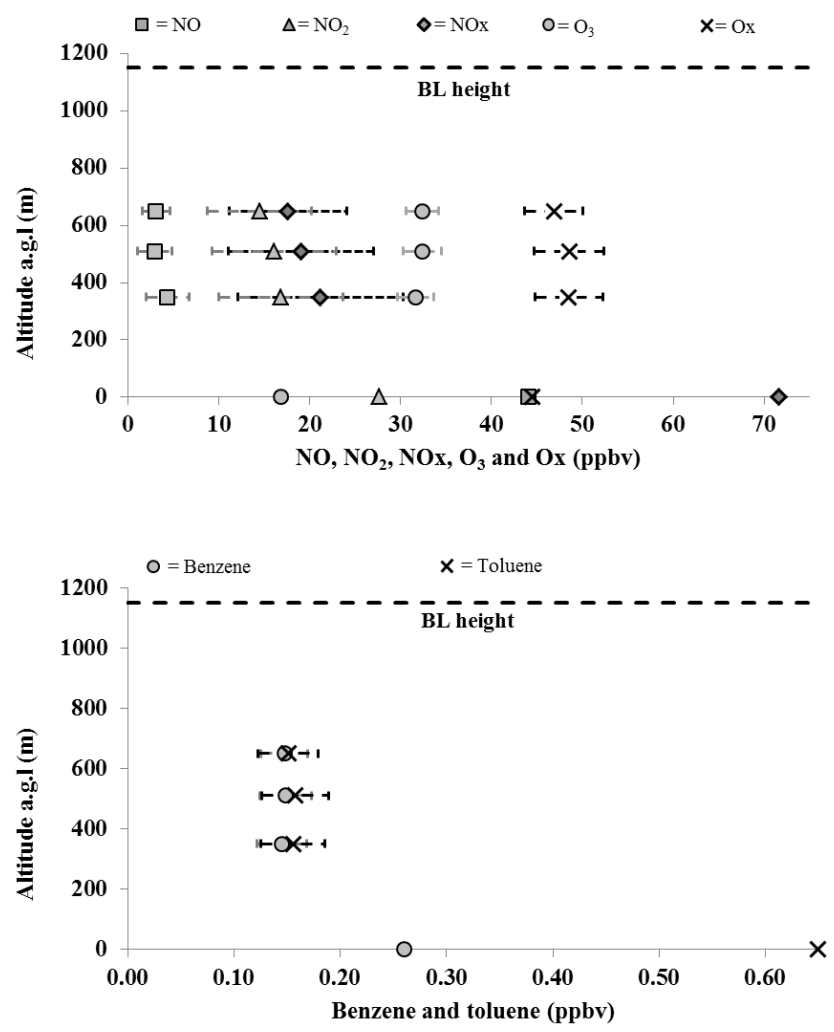

Figure 7. Average vertical profiles of $\mathrm{O}_{3}, \mathrm{NO}, \mathrm{NO}_{2}, \mathrm{O}_{x}$, benzene and toluene across London during RF1, 17:00-18:00 local time, on the 24 June 2013. X error bars represent standard deviation $(1 \sigma)$ of mixing ratios observed during each flight leg. Mixing ratio at ground level is hourly average from the LAQN Marylebone Road air quality monitoring station.

ratios for comparison were given as the arithmetic average and 1 standard deviation of the hourly measurements within the dispersion plume. The approximate transport times from Marylebone Road, Westminster and Eltham to the flight transect ranged between 3 and 7, 7 and 15, and 14 and $28 \mathrm{~min}$ respectively, calculated from the observed horizontal wind speed and the downwind or upwind distance for each ground station during each flight (Fig. S1 in the Supplement).

Figure 8 shows a linear regression analysis between airborne and ground mixing ratios of benzene, toluene, NO, $\mathrm{NO}_{2}, \mathrm{NO}_{x}$ and $\mathrm{O}_{3}$. Strong positive correlations are observed for all species at all three ground sites, with $R^{2}$ values ranging from 0.54 to $0.97(n=7)$. Ground mixing ratios of both VOCs and $\mathrm{NO}_{x}$ species were significantly higher at the Marylebone Road kerbside site relative to the urban background (Westminster) and suburban background (Eltham) sites. Average mixing ratios observed at ground level for benzene and toluene respectively were $0.12 \pm 0.05$ and $0.21 \pm 0.08 \mathrm{ppbv}$ at Marylebone Road and $0.07 \pm 0.01$ and $0.13 \pm 0.03 \mathrm{ppbv}$ at Eltham, with T/B ratios of $1.7-1.8 \mathrm{ppbv} \mathrm{ppbv}^{-1}$ indicative of vehicular emissions as the dominant source at both sites. $\mathrm{NO}_{x}$ mixing ratios were also significantly higher at Marylebone Road $(121.96 \pm 45.28 \mathrm{ppbv})$ than at Westminster $(40 \pm 4.45 \mathrm{ppbv})$ and Eltham $(10.02 \pm 4.28)$. For $\mathrm{O}_{3}$, the mean mixing ratios observed at Westminster $(13.56 \pm 4.9 \mathrm{ppbv})$ were lower than at Eltham (19.14 $\pm 3.2 \mathrm{ppbv})$, whilst the lowest mixing ratios were at the Marylebone Road site $(9.23 \pm 8.42 \mathrm{ppbv})$. The $\mathrm{O}_{3}$ mixing ratios at these sites are anticorrelated to that of NO (Fig. 8) through enhanced NO emission and subsequent titration of $\mathrm{O}_{3}$ in proximity to busy road networks.

A point also of interest is the fact that $\mathrm{NO} / \mathrm{NO}_{2}$ ratios were higher at the Marylebone Road site $(0.62 \pm 0.25)$ than at Westminster $(0.50 \pm 0.15)$ and Eltham $(0.25 \pm 0.09)$. Historically, vehicular diesel and petrol emissions of $\mathrm{NO}_{x}$ were dominated by emissions of $\mathrm{NO}\left(\mathrm{NO} / \mathrm{NO}_{2}\right.$ ratios of $\left.0.9 \leq\right)$. However, recent developments in diesel emission technology, specifically diesel oxidation catalysts and particulate filters, have caused significant increases in direct vehicular $\mathrm{NO}_{2}$ emissions in the UK and Europe. Current diesel emission control technology deliberately produces enhanced $\mathrm{NO}_{2}$ mixing ratios to oxidise and reduce black-carbon particulates in the vehicular exhaust gas (Carslaw and Rhys-Tyler, 2013). Increasing numbers of diesel vehicles in Central London with this emission reduction technology could have contributed to the low $\mathrm{NO} / \mathrm{NO}_{2}$ ratios observed from all three ground air monitoring stations during this study. This is in good agreement with the observed covariance of benzene, toluene and $\mathrm{NO}_{2}$ mixing ratios shown in Fig. 5, potentially indicating that these species have common sources, most likely from vehicular emission. However the measured $\mathrm{NO} / \mathrm{NO}_{2}$ concentration ratio at $360 \mathrm{~m}$ a.g.l is likely to be dominated by photochemistry rather than emission sources (Atkinson et al., 2000).

Airborne mixing ratios of $\mathrm{O}_{3}$ were consistently higher than those at ground level, consistent with the ground surface in London acting as a chemical sink for $\mathrm{O}_{3}$, which is in good agreement with the measured vertical profile of $\mathrm{O}_{3}$ shown in Fig. 7. Mixing ratios of the selective VOC and $\mathrm{NO}_{x}$ species observed at the roadside site at Marylebone Road were significantly higher than those of the airborne measurements. Assuming this difference is due entirely to mixing, this reduction in mixing ratio crudely indicates a dilution factor of 2-6 between the roadside site in the Marylebone Road and the $355 \mathrm{~m}$ sampling point. This agrees well with comparisons made during REPARTEE (REgents PARk and Tower Environmental Experiment) I, which concluded that there was a dilution factor of $\sim 5$ for $\mathrm{NO}_{x}$ mixing ratios between Marylebone Road and the $190 \mathrm{~m}$ sampling point on the BT tower (Harrison et al., 2012), well above the surrounding building height. Dilution factors for VOC and $\mathrm{NO}_{x}$ species at Westminster and Eltham ranged between 0.46 and 2.34; this is significantly lower than those observed at Marylebone Road. This difference in dilution factors is largely due to, firstly, the Marylebone Road measurement site being in central London, a very large source of VOCs and $\mathrm{NO}_{x}$, and being closest in proximity to the six-lane, frequently congested road. 

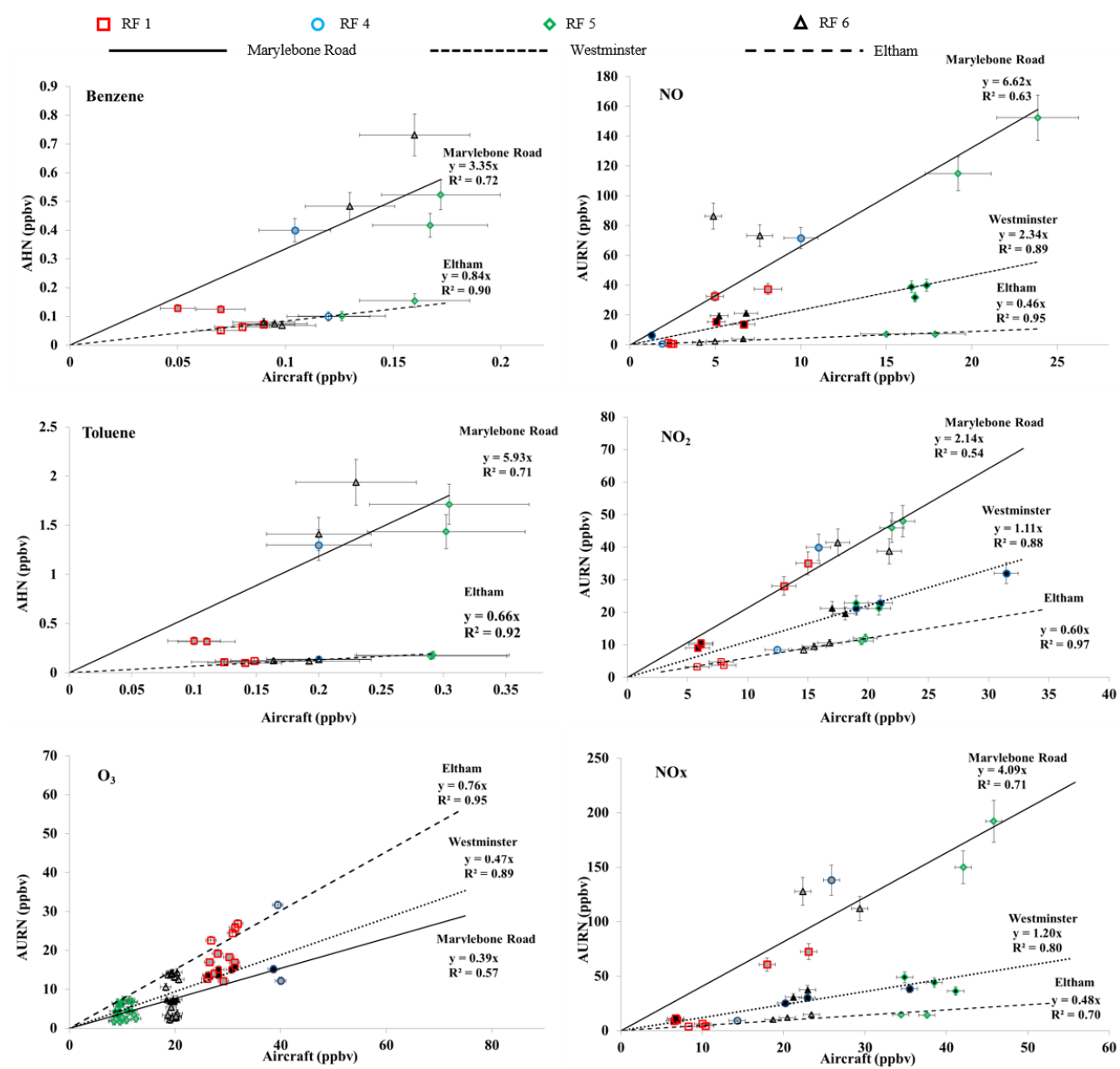

Figure 8. Linear regression analysis between airborne (at $360 \pm 10 \mathrm{~m}$ a.g.1.) and hourly ground measurements at Greenwich-Eltham (empty), Westminster-Horseferry road (black) and Marylebone Road (grey) from the LAQN monitoring network during RF1, 4, 5 and 6.

Secondly, Marylebone Road is within an urban street canyon whose orientation serves to maximise mixing ratios of emissions therein. Street canyons are not as well ventilated as more open locations, such as urban and suburban sites, which tends to result in increased surface mixing ratios (Pugh et al., 2012; Carslaw and Rhys-Tyler, 2013).

\section{Conclusions}

Measurements of VOCs, $\mathrm{NO}_{x}$ and $\mathrm{O}_{3}$ in the boundary layer were made in transects across Greater London at $360 \pm 10 \mathrm{~m}$ a.g.l. during the summer of 2013 , with a view to identifying the dominant $\mathrm{O}_{3}$ precursor sources within the region and to better understanding the effects of chemical interactions between these pollutants and meteorological variables on urban air quality. Observed benzene, toluene and $\mathrm{NO}_{x}$ mixing ratios across Greater London were mostly due to traffic emissions, with the highest mixing ratios observed over inner London, where the density of traffic and other pollutant sources is higher than over outer London. The highest
$\mathrm{T} / \mathrm{B}$ ratios $\left(1.8 \pm 0.5 \mathrm{ppbv}_{\mathrm{ppbv}}{ }^{-1}\right)$ observed within inner London are indicative of local vehicular sources. Linear regression analysis of VOC and $\mathrm{NO}_{x}$ species showed a covariance between benzene, toluene and $\mathrm{NO}_{2}$ mixing ratios, potentially indicating that their dominant sources are the same or are co-located throughout London. Modern diesel vehicles use emission control technology to reduce black-carbon emissions; however, this also enhances the $\mathrm{NO}_{2} / \mathrm{NO}$ ratio in the vehicle exhaust (Carslaw and Rhys-Tyler, 2013). As the measured $\mathrm{NO} / \mathrm{NO}_{2}$ concentration ratio at $360 \mathrm{~m}$ a.g.l. is likely to be dominated by photochemistry rather than emission sources, VOCs correlate well with $\mathrm{NO}_{2}$ but not $\mathrm{NO}$, due to its longer atmospheric lifetime (Atkinson et al., 2000).

Airborne mixing ratios were compared to kerbside data from three LAQN air quality ground monitoring stations within Greater London. Strong positive correlations were observed for $\mathrm{O}_{3}, \mathrm{NO}, \mathrm{NO}_{2}, \mathrm{NO}_{x}$, benzene and toluene species at all three ground sites, with $R^{2}$ values ranging from 0.54$0.97(n=7)$ suggesting that airborne mixing ratios were characteristic of surface mixing ratios during the analysis period. $\mathrm{NO}_{x}$ and VOC mixing ratios observed at the Maryle- 
bone Road air quality monitoring site were 2-6 times higher than those observed at $360 \pm 10 \mathrm{~m}$ a.g.l due to a combination of the monitoring site's proximity to the emission sources, photochemical aging and the dilution of the air mass during vertical mixing.

An increase in $\mathrm{NO}_{x}$ mixing ratios from $\sim 15$ to $30 \mathrm{ppbv}$ at $360 \pm 10 \mathrm{~m}$ a.g.l. during RF1 and RF5 was observed $\sim 20 \mathrm{~km}$ downwind of LHA. Our measurements tentatively support previous studies that suggest that even though Heathrow is an important emission source of $\mathrm{NO}_{x}$, observed mixing ratios of $\mathrm{NO}_{x}$, even quite close to the airport, are dominated by road traffic sources. Since LHA was $\sim 20 \mathrm{~km}$ upwind of the flight transects, these observed mixing ratios are likely to be heavily influenced by vehicular emissions during advection from LHA to the measurement location.

\section{The Supplement related to this article is available online at doi:10.5194/acp-15-5083-2015-supplement.}

Author contributions. M. D. Shaw and J. D. Lee redesigned the PTR-MS and $\mathrm{NO}_{x}$ chemiluminescence instruments for the aircraft. M. D. Shaw, J. D. Lee, A. Harvey and B. Davison designed the field experiment and carried it out. M. D. Shaw, J. D. Lee, A. Vaughan, R. M. Purvis, A. C. Lewis and C. N. Hewitt were responsible for the analysis and interpretation of the data.

Acknowledgements. We thank the UK Natural Environment Research Council (grant NE/J00779X/1) and the Department of Environment, Food and Rural Affairs for funding. We thank Captain Carl Joseph, co-pilot James Johnson and instrumental engineer Thomas Millard (ARSF) for their expert support during the flights and James Hopkins and Shallini Punjabi (National Centre for Atmospheric Science, University of York, UK) for the WAS TD-GC-FID benzene and toluene concentration data.

Edited by: R. McLaren

\section{References}

Atkinson, R.: Atmospheric chemistry of VOCs and $\mathrm{NO}_{x}$, Atmos. Environ., 34, 2063-2101, 2000.

Beswick, K. M., Gallagher, M. W., Webb, A. R., Norton, E. G., and Perry, F.: Application of the Aventech AIMMS20AQ airborne probe for turbulence measurements during the Convective Storm Initiation Project, Atmos. Chem. Phys., 8, 5449-5463, doi:10.5194/acp-8-5449-2008, 2008.

Beyrich, F., Weisensee, U., Sprung, D., and Güsten, H.: Comparative analysis of sodar and ozone profile measurements in a complex structured boundary layer and implications for mixing height estimation, Bound.-Lay. Meteorol., 81, 1-9, 1996.
Cao, X.-L. and Hewitt, C. N.: Thermal desorption efficiencies for different adsorbate/adsorbent systems typically used in air monitoring programmes, Chemosphere, 27, 695-705, 1993.

Cao, X.-L. and Hewitt, C. N.: Study of the degradation by ozone of adsorbents and of hydrocarbons adsorbed during the passive sampling of air, Environ. Sci. Technol., 28, 757-762, 1994a.

Cao, X.-L. and Hewitt, C. N.: Build-up of artifacts on adsorbents during storage and its effect on passive sampling and gas chromatography-flame ionization detection of low concentrations of volatile organic compounds in air, J. Chromatogr. A, 688 , 368-374, 1994b.

Carslaw, D. C. and Rhys-Tyler, G.: New insights from comprehensive on-road measurements of $\mathrm{NO}_{x}, \mathrm{NO}_{2}$ and $\mathrm{NH}_{3}$ from vehicle emission remote sensing in London, UK, Atmos. Environ., 81, 339-347, 2013.

Carslaw, D. C., Beevers, S. D., Ropkins, K., and Bell, M. C.: Detecting and quantifying aircraft and other on-airport contributions to ambient nitrogen oxides in the vicinity of a large international airport, Atmos. Environ., 40, 5424-5434, 2006.

de Gouw, J. and Warneke, C.: Measurements of volatile organic compounds in the earth's atmosphere using proton-transferreaction mass spectrometry, Mass Spectrom. Rev., 26, 223-257, 2007.

de Gouw, J., Warneke, C., Holzinger, R., Klüpfel, T., and Williams, J.: Inter-comparison between airborne measurements of methanol, acetonitrile and acetone using two differently configured PTR-MS instruments, International J. Mass Spectrom., 239, 129-137, 2004.

Dueñas, C., Fernández, M., Cañete, S., Carretero, J., and Liger, E.: Assessment of ozone variations and meteorological effects in an urban area in the Mediterranean Coast, Sci. Total Environ., 299, 97-113, 2002.

Glaser, K., Vogt, U., Baumbach, G., Volz-Thomas, A., and Geiss, H.: Vertical profiles of $\mathrm{O}_{3}, \mathrm{NO}_{2}, \mathrm{NO}_{x}, \mathrm{VOC}$, and meteorological parameters during the Berlin Ozone Experiment (BERLIOZ) campaign, J. Geophys. Res.-Atmos., 108, 8253, doi:10.1029/2002JD002475, 2003.

Güsten, H., Heinrich, G., and Sprung, D.: Nocturnal depletion of ozone in the Upper Rhine Valley, Atmos. Environ., 32, 11951202, 1998.

Harrison, R. M., Dall'Osto, M., Beddows, D. C. S., Thorpe, A. J., Bloss, W. J., Allan, J. D., Coe, H., Dorsey, J. R., Gallagher, M., Martin, C., Whitehead, J., Williams, P. I., Jones, R. L., Langridge, J. M., Benton, A. K., Ball, S. M., Langford, B., Hewitt, C. N., Davison, B., Martin, D., Petersson, K. F., Henshaw, S. J., White, I. R., Shallcross, D. E., Barlow, J. F., Dunbar, T., Davies, F., Nemitz, E., Phillips, G. J., Helfter, C., Di Marco, C. F., and Smith, S.: Atmospheric chemistry and physics in the atmosphere of a developed megacity (London): an overview of the REPARTEE experiment and its conclusions, Atmos. Chem. Phys., 12, 3065-3114, doi:10.5194/acp-12-3065-2012, 2012.

Hayward, S., Hewitt, C., Sartin, J., and Owen, S.: Performance characteristics and applications of a proton transfer reaction-mass spectrometer for measuring volatile organic compounds in ambient air, Environ. Sci. Technol., 36, 1554-1560, 2002.

Heeb, N. V., Forss, A.-M., Bach, C., Reimann, S., Herzog, A., and Jäckle, H. W.: A comparison of benzene, toluene and C2benzenes mixing ratios in automotive exhaust and in the suburban atmosphere during the introduction of catalytic converter 
technology to the Swiss Car Fleet, Atmos. Environ., 34, 31033116, 2000.

Hewitt, C., Hayward, S., and Tani, A.: The application of proton transfer reaction-mass spectrometry (PTR-MS) to the monitoring and analysis of volatile organic compounds in the atmosphere, J. Environ. Monitor., 5, 1-7, 2003.

Hopkins, J. R., Lewis, A. C., and Read, K. A.: A two-column method for long-term monitoring of non-methane hydrocarbons (NMHCs) and oxygenated volatile organic compounds (oVOCs), J. Environ. Monitor., 5, 8-13, 2003.

Hopkins, J. R., Evans, M. J., Lee, J. D., Lewis, A. C., H Marsham, J., McQuaid, J. B., Parker, D. J., Stewart, D. J., Reeves, C. E., and Purvis, R. M.: Direct estimates of emissions from the megacity of Lagos, Atmos. Chem. Phys., 9, 8471-8477, doi:10.5194/acp9-8471-2009, 2009.

Hu, S., Paulson, S. E., Fruin, S., Kozawa, K., Mara, S., and Winer, A. M.: Observation of elevated air pollutant concentrations in a residential neighborhood of Los Angeles California using a mobile platform, Atmos. Environ., 51, 311-319, 2012.

Im, U., Incecik, S., Guler, M., Tek, A., Topcu, S., Unal, Y. S., Yenigun, O., Kindap, T., Odman, M. T., and Tayanc, M.: Analysis of surface ozone and nitrogen oxides at urban, semi-rural and rural sites in Istanbul, Turkey, Sci. Total Environ., 443, 920-931, 2013.

Jobson, B. T., Volkamer, R. A., Velasco, E., Allwine, G., Westberg, H., Lamb, B. K., Alexander, M. L., Berkowitz, C. M., and Molina, L. T.: Comparison of aromatic hydrocarbon measurements made by PTR-MS, DOAS and GC-FID during the MCMA 2003 Field Experiment, Atmos. Chem. Phys., 10, 1989-2005, doi:10.5194/acp-10-1989-2010, 2010.

Kansal, A.: Sources and reactivity of NMHCs and VOCs in the atmosphere: A review, J. Hazard. Mater., 166, 17-26, 2009.

Karl, T., Apel, E., Hodzic, A., Riemer, D. D., Blake, D. R., and Wiedinmyer, C.: Emissions of volatile organic compounds inferred from airborne flux measurements over a megacity, Atmos. Chem. Phys., 9, 271-285, doi:10.5194/acp-9-271-2009, 2009.

Langford, B., Nemitz, E., House, E., Phillips, G. J., Famulari, D., Davison, B., Hopkins, J. R., Lewis, A. C., and Hewitt, C. N.: Fluxes and concentrations of volatile organic compounds above central London, UK, Atmos. Chem. Phys., 10, 627-645, doi:10.5194/acp-10-627-2010, 2010.

Lee, J., Moller, S., Read, K., Lewis, A., Mendes, L., and Carpenter, L.: Year-round measurements of nitrogen oxides and ozone in the tropical North Atlantic marine boundary layer, J. Geophys. Res., 114, D21302, doi:10.1029/2009JD011878, 2009.

Lee, J., Helfter, C., Purvis, R., Beavers, S., Carslaw, D., Lewis, A., Moller, S., Nemitz, E., and Tremper, A.: Measurement $\mathrm{NO}_{x}$ fluxes from a tall tower above central London, UK and comparison with emissions inventories, Environ. Sci. Technol., 49, 10251034 doi:10.1021/es5049072, 2015.

Lu, W. and Wang, X.: Interaction patterns of major air pollutants in Hong Kong territory, Sci. Total Environ., 324, 247-259, 2004.

Marr, L. C., Moore, T. O., Klapmeyer, M. E., and Killar, M. B.: Comparison of $\mathrm{NO}_{x}$ Fluxes Measured by Eddy Covariance to Emission Inventories and Land Use, Environ. Sci. Technol., 47, 1800-1808, doi:10.1021/es303150y, 2013.

Mazzeo, N. A., Venegas, L. E., and Choren, H.: Analysis of NO, $\mathrm{NO}_{2}, \mathrm{O}_{3}$ and $\mathrm{NO}_{x}$ concentrations measured at a green area of Buenos Aires City during wintertime, Atmos. Environ., 39, 3055-3068, 2005.

Na, K., Moon, K.-C., and Kim, Y. P.: Source contribution to aromatic VOC concentration and ozone formation potential in the atmosphere of Seoul, Atmos. Environ., 39, 5517-5524, 2005.

Newchurch, M., Ayoub, M., Oltmans, S., Johnson, B., and Schmidlin, F.: Vertical distribution of ozone at four sites in the United States, J. Geophys. Res.-Atmos., 108, ACH 9-1-ACH 917, 2003.

Ohta, T. and Ohyama, T.: A set of rate constants for the reactions of $\mathrm{OH}$ radicals with aromatic hydrocarbons, B. Chem. Soc. Jpn., 58, 3029-3030, 1985.

Pollack, I. B., Lerner, B. M., and Ryerson, T. B.: Evaluation of ultraviolet light-emitting diodes for detection of atmospheric $\mathrm{NO}_{2}$ by photolysis-chemiluminescence, J. Atmos. Chem., 65, 111-125, 2010.

Pudasainee, D., Sapkota, B., Bhatnagar, A., Kim, S.-H., and Seo, Y.-C.: Influence of weekdays, weekends and bandhas on surface ozone in Kathmandu valley, Atmos. Res., 95, 150-156, 2010.

Pugh, T. A., MacKenzie, A. R., Whyatt, J. D., and Hewitt, C. N.: Effectiveness of green infrastructure for improvement of air quality in urban street canyons, Environ. Sc. Technol., 46, 7692-7699, 2012.

Rogers, T., Grimsrud, E., Herndon, S., Jayne, J., Kolb, C. E., Allwine, E., Westberg, H., Lamb, B., Zavala, M., and Molina, L.: On-road measurements of volatile organic compounds in the Mexico City metropolitan area using proton transfer reaction mass spectrometry, Int. J. Mass Spectrom., 252, 26-37, 2006.

Schäfer, K., Heland, J., Lister, D. H., Wilson, C. W., Howes, R. J., Falk, R. S., Lindermeir, E., Birk, M., Wagner, G., and Haschberger, P.: Nonintrusive optical measurements of aircraft engine exhaust emissions and comparison with standard intrusive techniques, Appl. Optics, 39, 441-455, 2000.

Schürmann, G., Schäfer, K., Jahn, C., Hoffmann, H., Bauerfeind, M., Fleuti, E., and Rappenglück, B.: The impact of NO, CO and VOC emissions on the air quality of Zurich airport, Atmos. Environ., 41, 103-118, 2007.

Spicer, C. W., Holdren, M. W., Riggin, R. M., and Lyon, T. F.: Chemical composition and photochemical reactivity of exhaust from aircraft turbine engines, Ann. Geophys., 12, 944-955, doi:10.1007/s00585-994-0944-0, 1994.

Stutz, J., Alicke, B., Ackermann, R., Geyer, A., White, A., and Williams, E.: Vertical profiles of $\mathrm{NO}_{3}, \mathrm{~N}_{2} \mathrm{O}_{5}, \mathrm{O}_{3}$, and $\mathrm{NO}_{x}$ in the nocturnal boundary layer: 1 . Observations during the Texas Air Quality Study 2000, J. Geophys. Res.-Atmos., 109, D12306, doi:10.1029/2003JD004209, 2004.

Taipale, R., Ruuskanen, T. M., Rinne, J., Kajos, M. K., Hakola, H., Pohja, T., and Kulmala, M.: Technical Note: Quantitative long-term measurements of VOC concentrations by PTR-MS measurement, calibration, and volume mixing ratio calculation methods, Atmos. Chem. Phys., 8, 6681-6698, doi:10.5194/acp8-6681-2008, 2008.

Valach, A., Langford, B., Nemitz, E., MacKenzie, A., and Hewitt, C.: Concentrations of selected volatile organic compounds at kerbside and background sites in central London, Atmos. Environ., 95, 456-467, doi:10.1016/j.atmosenv.2014.06.052, 2014.

Velasco, E., Márquez, C., Bueno, E., Bernabé, R. M., Sánchez, A., Fentanes, O., Wöhrnschimmel, H., Cárdenas, B., Kamilla, A., Wakamatsu, S., and Molina, L. T.: Vertical distribution of 
ozone and VOCs in the low boundary layer of Mexico City, Atmos. Chem. Phys., 8, 3061-3079, doi:10.5194/acp-8-3061-2008, 2008.

Wang, S., Ackermann, R., Geyer, A., Doran, J. C., Shaw, W. J., Fast, J. D., Spicer, C. W., and Stutz, J.: Vertical variation of nocturnal $\mathrm{NO}_{x}$ chemistry in the urban environment of Phoenix, Extended Abstracts, Fifth Conference on Atmospheric Chemistry in the 83rd AMS Annual Meeting, 2003,

Warneke, C., Van der Veen, C., Luxembourg, S., De Gouw, J., and Kok, A.: Measurements of benzene and toluene in ambient air using proton-transfer-reaction mass spectrometry: calibration, humidity dependence, and field intercomparison, Int. J. Mass Spectrom., 207, 167-182, 2001.
Watson, J. G., Chow, J. C., and Fujita, E. M.: Review of volatile organic compound source apportionment by chemical mass balance, Atmos. Environ., 35, 1567-1584, 2001.

Wesely, M. and Hicks, B.: A review of the current status of knowledge on dry deposition, Atmos. Environ., 34, 2261-2282, 2000. 